Feature Article

\title{
Real-World Applications and Instructional Representations Among Prospective Elementary Science Teachers*
}

\section{Elizabeth A. Davis}

School of Education, University of Michigan, Ann Arbor, MI 48109-1259, U.S.A.

\section{Debra Petish}

Glenbrook South High School, Glenview, IL 60026, U.S.A.

\begin{abstract}
This paper explores new elementary teachers' instructional representations and how these are related to their science subject matter knowledge. One pair of prospective elementary teachers studied here exhibited a well-integrated, principled, and scientifically accurate understanding of the science they were teaching. The other pair exhibited less scientifically accurate and integrated knowledge. The pair with stronger subject matter knowledge developed instructional representations that were more scientifically and pedagogically appropriate. A perspective on one aspect of pedagogical content knowledge—knowledge of instructional representations-is presented. Real-world applications are hypothesized to play a crucial mediating role for elementary teachers. The paper concludes with a discussion of implications for elementary science teacher educators and researchers, including the importance of attending to how prospective teachers apply science knowledge to real-world situations.
\end{abstract}

\section{Introduction}

Teaching inquiry-oriented science is challenging. Understanding subject matter is necessary, but not sufficient (Ball \& Bass, 2000; Grossman, 1990; Magnusson, Krajcik, \& Borko, 1999) for planning and enacting inquiry-oriented science lessons of the type recommended by Project 2061's Benchmarks for Science Literacy (American Association for the Advancement of Science, 1993), the National Science Education Standards (National Research Council, 1996), and other reform documents. Prospective elementary science teachers face particular challenges in teaching inquiry-oriented science. Elementary teachers generally have less science subject matter knowledge than do secondary teachers (Anderson \& Mitchener, 1994). Most elementary teachers teach at least language arts, mathematics, social studies, and science; some also teach art, music, physical education, computers, and other subjects. 
Even within the subject of science, elementary teachers face a daunting task since they are responsible for all areas of science-including life, physical, and earth sciences. Prospective elementary teachers-simply by virtue of being novices-also do not have the general pedagogical knowledge veteran teachers have gained through years of experience. Perhaps most critical, prospective elementary teachers may not anticipate the range of their students' ideas about science, know about available science curricular materials (e.g., FOSS, SCIS) or instructional approaches (e.g., the learning cycle, project-based science), or recognize effective instructional representations. These are all crucial aspects of what Shulman (1986) termed pedagogical content knowledge (PCK).

We explore relationships between subject matter knowledge and pedagogical content knowledge, paying particular attention to prospective teachers' instructional representations of science topics. For example, a science teacher might use water flowing through a hose as an instructional representation when teaching about electricity and would need to understand the ways in which the flow of electrons is similar to and different from the flow of water (McDiarmid, Ball, \& Anderson, 1989). We also pay particular attention to the ways in which the prospective teachers interpret and use real-world applications. By real-world applications, we mean situations in which scientific principles are applied - usually implicitly_to everyday situations. We elaborate on our meaning of real-world applications below.

Important work has explored what may constitute and influence a teacher's PCK (e.g., Fernandez-Balboa \& Stiehl, 1995; Gess-Newsome, 1999; Grossman, 1990; Magnusson et al., 1999; Smith \& Neale, 1989; van Driel, Verloop, \& de Vos, 1998). Following the calls of van Driel et al. and others for empirical work on the development of PCK, in this paper we characterize prospective teachers' knowledge and describe ways in which subject matter knowledge may relate to pedagogical decisions. Our primary research question is "What does pedagogical content knowledge-especially knowledge of instructional representations-look like among prospective teachers?" We then hypothesize about the role of real-world applications in the development of this aspect of PCK.

In brief, we show that inappropriate real-world applications of science topics may be indicators of weaknesses in prospective teachers' science subject matter knowledge, as well as harbingers of problematic pedagogical moves in the future, such as the use of inappropriate instructional representations. On the other hand, we also demonstrate how appropriate real-world applications can promote the development of strong science subject matter knowledge and PCK.

Through this work, we hope to inform science teacher education researchers and practitioners. The perspective on instructional representations that we present may contribute to researchers' knowledge of the development of PCK among teachers, in general, as well as more specifically among new elementary science teachers. It may also help science teacher educators be more effective and efficient at identifying and dealing with strengths and areas of concern among their students, preservice science teachers. 


\section{Subject Matter Knowledge and the Development of Pedagogical Content Knowledge}

We use a knowledge integration perspective (Linn, Eylon, \& Davis, 2004) in our analyses of subject matter knowledge. This view of how people learn is consistent with other views emerging from current research (Bransford, Brown, \& Cocking, 1999). In the knowledge integration perspective, learners add new ideas to their repertoire, linking some and distinguishing between others (Linn \& Hsi, 2000). Ideas may include scientific principles, definitions, and real-world and classroombased experiences (Davis, 2003, 2004; Linn \& Eylon, 1996). Science learners who appropriately link several types of ideas have a better understanding of science content. But not all knowledge is equally useful, relevant, valid, or reliable. For example, two principles may be equally valid, yet if one is more explanatory, it will be more useful in understanding a scientific phenomenon. Likewise, scientifically accurate (i.e., given the current state of scientific knowledge) principles are clearly more useful than are inaccurate principles. In this study, we characterize the types of ideas articulated by the prospective teachers as a measure of their subject matter knowledge integration. We also describe the accuracy and explanatory power of their scientific ideas as further measures of the quality of their subject matter knowledge.

Little is known about how teachers develop pedagogical content knowledge, though two necessary ingredients are typically assumed to be subject matter knowledge and experience in teaching (e.g., Magnusson et al., 1999; van Driel et al., 1998; van Driel, De Jong, \& Verloop, 2002). In fact, subject matter knowledge is typically perceived to be "a prerequisite, preceding the development of PCK" (van Driel et al., 1998, p. 681). In experienced teachers, the subject matter knowledge and PCK may become integrated to form "content knowledge complexes" (Sherin, 2002, p. 124), but new teachers have not yet had the classroom experiences that would promote much of this integration.

In fact, prospective teachers often demonstrate little explicit pedagogical content knowledge for specific science topics (Lederman, Gess-Newsome, \& Latz, 1994; van Driel et al., 1998). Because of the high demands placed on elementary teachers, as described above, elementary teachers tend to demonstrate weaker subject matter knowledge in science than do their secondary counterparts (Anderson \& Mitchener, 1994). Yet given a constructivist view of learning, prospective elementary teachers must have some foundation on which to develop PCK, at least in its early forms. For example, beginning elementary teachers may rely on science activities they have taught or experienced as students as a way to help them develop PCK in science (Appleton, 2003).

It is our goal to describe one aspect of prospective elementary teachers' PCK and to hypothesize about its development. We focus here on instructional representations since this aspect of pedagogical content knowledge seems reasonable to expect new teachers to begin to develop, even without much knowledge of learners and curriculum, because of their experiences in the physical world and as students in classrooms. Our basic premise is that new elementary teachers face daunting challenges, and a better understanding of their knowledge base and how it might 
develop will provide teacher educators with improved ideas about how to support them in becoming effective teachers.

\section{Instructional Representations and Real-World Applications}

Being able to represent and illustrate scientific concepts so children can understand them is a critical aspect of science teaching. Connecting scientific ideas to examples in the real world is one way of representing ideas and promotes student learning (e.g., Clement, 1982; Linn \& Songer, 1991; Minstrell, 1989). On the other hand, individuals' experiences with the real world also can foster alternative conceptions, or nonscientific ideas. Individuals can understandably become confused about how scientific principles map onto what they experience outside or at home (Driver, Guesne, \& Tiberghien, 1985; Linn \& Songer, 1991; White, 1993); for example, they may decide that balls roll forever in science class, but come to rest on the playground (Linn \& Hsi, 2000). As such, helping prospective teachers make appropriate links between scientific principles and the application of those principles is an important goal for science teacher educators.

Instructional representations can be based on analogies (e.g., Yerrick, Doster, Nugent, Parke, \& Crawley, 2003) or can take the form of demonstrations and activities (e.g., Zembal-Saul, Krajcik, \& Blumenfeld, 2002) and illustrations and examples (e.g., McDiarmid et al., 1989). We do not include here representations of data (e.g., Roth, McGinn, \& Bowen, 1998; Wu, 2002), nor are we referring to mental representations. We are most interested in instructional representations based on what Yerrick and colleagues (2003) called analogies and we call real-world applications. We use the term real-world applications because we are particularly interested in analogies grounded in typical, real-life experiences.

Developing instructional representations is related to both subject matter and pedagogy (Treagust \& Harrison, 2000). Teachers with better subject matter knowledge are more able to develop explanatory representations (Hashweh, 1987), and it can be difficult for prospective teachers to understand and use analogical instructional representations, which often involve real-world application of scientific principles, if they do not hold strong subject matter knowledge (Yerrick et al., 2003). Preservice teachers may interpret analogies provided in curriculum materials in a way that renders them scientifically inappropriate, or they may overgeneralize analogies to too many concepts (Yerrick et al., 2003). They may also give equal or greater weight to analogies they develop as opposed to those provided in curriculum materials, even though those personal analogies are often scientifically inappropriate for the concepts at hand (Yerrick et al., 2003).

McDiarmid and his colleagues (1989) identified four criteria for good instructional representations: Representations should be (a) scientifically correct and appropriate, (b) comprehensible, (c) helpful for promoting learning, and (d) reasonable for the particular instructional context. In this study, we focus much of our attention on these criteria for instructional representations, summarizing them by noting that instructional representations should be relevant, as well as scientifically and pedagogically appropriate. 
Developing — or even recognizing — scientifically and pedagogically appropriate instructional representations is challenging, but Zembal-Saul, Blumenfeld, and Krajcik (2000) described how prospective elementary science teachers improved in their ability to develop appropriate instructional representations over multiple cycles of planning, teaching, and reflection. With significant support from their teacher educators, these beginning teachers were able to consider science content and to develop increasingly appropriate ways of representing the content to the learners (Zembal-Saul et al., 2000); with support from their cooperating teachers and other features of their student teaching contexts, they could continue to do so during student teaching (Zembal-Saul et al., 2002). So we can be better positioned to know what support might be most helpful, we were interested in what prospective teachers do with regard to instructional representations before receiving that extensive support.

We assume that the ways prospective teachers connect real-world situations to science ideas may eventually be used as representations in teaching. Ma (1999), for example, described the importance of teachers being able to design problem contexts that make appropriate links to the real world; teachers must, for example, be able to recognize a real-world application of the multiplication of fractions before they can design a lesson with an instructional representation intended to teach this topic to children (Hartman, 2004). Thus, we investigate explicit examples of instructional representations, as well as implicit examples that may develop into instructional representations later. By explicit instructional representations, we mean examples that the prospective teachers themselves develop or identify for the purpose of representing science content to students, such as a lesson involving playing music to explore pitch and volume. By implicit instructional representations, we mean examples that are not explicitly discussed in terms of their use with children; the prospective teachers present these in a way that implies they may later be used for instruction. For example, one could make an analogy between humans and plants when discussing plant parts with an interviewer, outside of the context of describing an actual lesson. The explicit and implicit instructional representations investigated here involve a real-world application - that is, a connection to the physical world.

\section{Methods}

The study took place during the third semester of a relatively small undergraduate teacher preparation program. The four-semester program emphasizes teaching consonant with recommendations of teacher education reform calls (e.g., Interstate New Teacher Assessment and Support Consortium, 1992; National Council for Accreditation of Teacher Education, 1987) and subject-matter standards documents (e.g., American Association for the Advancement of Science, 1993; National Research Council, 1996). Each semester prior to student teaching, the prospective teachers spend $6 \mathrm{~h}$ per week in field (i.e., practicum) classrooms and are typically placed in the field classrooms in pairs. These field experiences are tied to the education courses the prospective teachers take concurrently. 
The general studies requirements for the teacher preparation program at the time of this study required all prospective teachers to take one course in biological science, one in physical science (either chemistry or physics), and one in earth science (including astronomy, geology, atmospheric science, etc.). In other words, the science background, in terms of college coursework, is likely to be minimal for these prospective teachers. The general studies requirements also included coursework in the humanities, social sciences, mathematics, and creative arts. The prospective teachers in the program receive their degree in the school of education, but they also have major and minor subject area concentrations in language arts, social studies, mathematics, science, or fine arts; none of the participants in this study were science majors or minors. The prospective teachers also, of course, have professional preparation requirements. For example, during their four semesters in the program, they take methods courses in social studies, literacy, mathematics, and science, in addition to other education coursework.

The prospective teachers' elementary science methods course was the specific context for this study. The first author (Davis) taught the course, and the second author (Petish) served as the prospective teachers' field supervisor. All 25 prospective teachers were 4th- or 5th-year seniors and planned to student teach the following semester. Most were Caucasian and female.

\section{Participants and Data Sources}

A qualitative case study research design was adopted (Merriam, 1988; Stake, 2000; Wolcott, 1994). Potential participants were chosen if both members of a pair of prospective teachers had agreed to participate. We used a purposive sampling strategy (Merriam, 1988) to select five pairs who chose diverse subject area concentrations for their units and who seemed articulate and verbal, both in writing and orally. We selected these prospective teachers because we determined we could learn the most from them (Merriam, 1988; Stake, 2000). Later, two individuals dropped out of the interview portion of the study, leaving three pairs and two individuals. The third remaining pair was dropped from the current analysis because one member of the pair was particularly reticent in the interviews. We focus, then, on two pairs of prospective teachers: Lynn, Stef, Jackie, and Terry. (These are pseudonyms intended to be gender-neutral.)

Table 1 summarizes some of the relevant background characteristics of these 4 individuals. This background information should provide a sense of who these prospective teachers were, and in particular, how they approached and were prepared for science teaching. This information includes their major and minor subject concentration within the school of education and an informal account of the science coursework they had experienced in high school and college (according to a short survey they each filled out on the first day of the science methods course). The short survey also asked them to write a word or phrase that described how they felt about science. Table 1 supplies these descriptors, as well.

The four prospective teachers are similar to and appear representative of their peers in most ways. As noted above, none of these prospective teachers had a major 
Table 1

Background Characteristics of the Participants

\begin{tabular}{|c|c|c|c|c|}
\hline & $\begin{array}{l}\text { SOE major } \\
\text { concentration }\end{array}$ & $\begin{array}{l}\text { SOE minor } \\
\text { concentration }\end{array}$ & Science courses & $\begin{array}{l}\text { Word } \\
\text { about feelings } \\
\text { about science }\end{array}$ \\
\hline Lynn & Social studies & Language arts & $\begin{array}{l}\text { Many; across life, physical, } \\
\text { and earth science; in high } \\
\text { school and college }\end{array}$ & Rigid \\
\hline Stef & Language arts & Social studies & $\begin{array}{l}\text { Some; life and physical } \\
\text { science are covered; no } \\
\text { earth science yet; cannot } \\
\text { distinguish between high } \\
\text { school and college } \\
\text { courses }\end{array}$ & Good/excited \\
\hline Jackie & Language arts & Social studies & $\begin{array}{l}\text { Some; life and physical } \\
\text { science are covered; no } \\
\text { earth science yet; some } \\
\text { courses in college }\end{array}$ & $\begin{array}{l}\text { What? (possibly to } \\
\text { indicate } \\
\text { confusion) }\end{array}$ \\
\hline Terry & Language arts & Social studies & $\begin{array}{c}\text { Minimal; life and physical } \\
\text { science are covered; no } \\
\text { earth science yet; only } \\
\text { biology so far in college }\end{array}$ & Skeptical \\
\hline
\end{tabular}

or minor in science. One (Lynn) had numerous science courses and one (Terry) had minimal science coursework. Only one of the prospective teachers (Stef) wrote a descriptive phrase that indicated a positive feeling toward science.

We were interested in how these prospective teachers made sense of teaching and learning challenges in science, so we focused on their preparation for instruction. Data sources included written course work (a unit plan) and interviews. For the unit plan, completed in three phases, prospective teachers wrote a rationale, described the subject matter knowledge a teacher needed, developed an instructional representation to use with children, and fully developed 5 days worth of instruction plus 1 day of assessment (see Figure 1). Prospective teachers typically worked with their practicum partner and taught at least 2 days from the unit in their placement classrooms. Lynn and Stef developed a 2nd-grade unit plan focused on the topic of sound. Jackie and Terry developed a 2nd-grade unit plan focused on the topic of plants.

Pairs were interviewed twice during the semester. The semistructured interviews centered on participants' subject matter knowledge and pedagogical content knowledge in the area in which they were developing their unit plan. In Interview 1 , the prospective teachers were asked a series of questions about their choice of the topic of their unit and their confidence in understanding and teaching that topic. Because we were interested in how they made sense of real-world applications of science ideas, we provided multiple real-world scenarios and asked the prospective teachers to explain them scientifically. For example, we asked Stef and Lynn about 


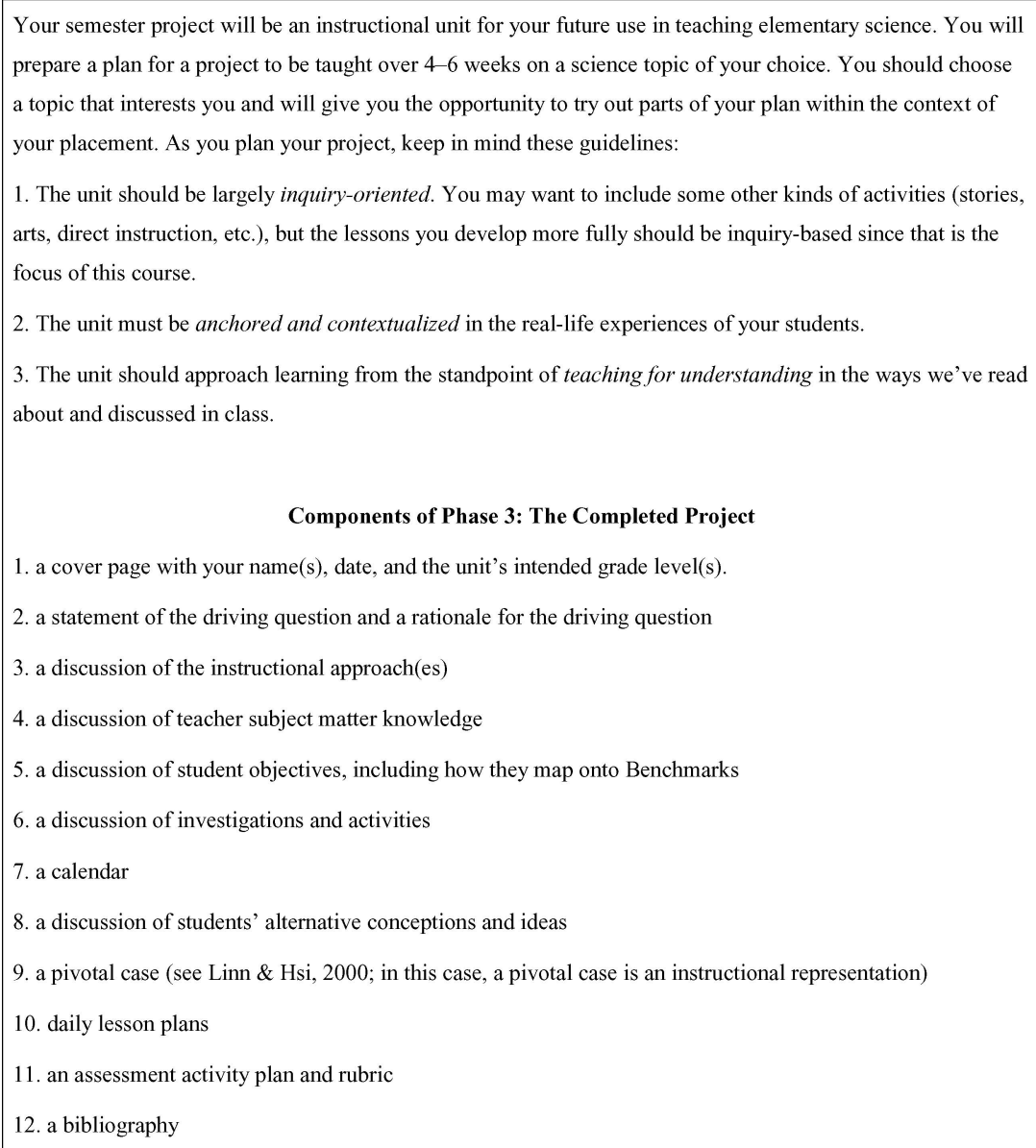

Figure 1. Abbreviated unit plan assignment. (Students' version included much more detail about the three phases of the assignment.)

musical instruments to learn more about their ideas about pitch, frequency, volume, and how sound travels. We asked Jackie and Terry about the environmental effects of deforestation of rain forests to learn more about their understanding of photosynthesis and plant parts. In Interview 2, at the end of the semester, the participants were asked follow-up questions about science content from Interview 1. In addition, for each pair, we selected a lesson plan from their unit plan, and asked them a series of questions about why they included that lesson plan in their unit and about their learning goals for the lesson. This allowed us to better understand their reasoning, including how they talked about any instructional representations. We closed Interview 2 with a series of questions about changes they made in their unit plan over the course of the semester. 


\section{Analytic Framework and Data Analysis}

Table 2 summarizes how the data from the unit plans were coded and analyzed in terms of subject matter knowledge and pedagogical content knowledge. We attempted to account for the inherent differences between the two topics-sound and plants - by being systematic in our data analyses.

As described above, subject matter knowledge should be well-integrated, accurate, and explanatory. To measure integration of subject matter knowledge, we characterized and counted the types of ideas the teachers brought to bear, such as scientific principles, definitions, or experiences (see Table 3). This gave a sense of the range and extent of ideas that the teachers added to their repertoires and linked to one another. This was important because learners who connect different types of ideas have a better understanding of science concepts (Linn et al., 2004; Linn

Table 2

Summary of Data Sources (in Unit Plans) and Analyses

\begin{tabular}{|c|c|c|}
\hline Data source in unit plan & Coding construct & $\begin{array}{l}\text { Goal of analysis: } \\
\text { to characterize... }\end{array}$ \\
\hline \multirow[t]{3}{*}{$\begin{array}{l}\text { Written explanation of } \\
\text { subject matter } \\
\text { knowledge }\end{array}$} & $\begin{array}{l}\text { Types of ideas (and counts thereof): } \\
\text { principle, definition, real-world } \\
\text { experience, classroom-based experience }\end{array}$ & SMK (integration) \\
\hline & $\begin{array}{l}\text { Accurate and inaccurate principles and } \\
\text { definitions }\end{array}$ & SMK (accuracy) \\
\hline & Level of explanation of principles & $\begin{array}{l}\text { SMK } \\
\quad \text { (explanatory } \\
\text { power) }\end{array}$ \\
\hline \multirow{3}{*}{$\begin{array}{l}\text { Implicit instructional } \\
\text { representations }\end{array}$} & Relevance & SMK \\
\hline & Scientific appropriateness & SMK \\
\hline & Pedagogical appropriateness & PCK \\
\hline \multirow[t]{4}{*}{$\begin{array}{l}\text { Explicit instructional } \\
\text { representations }\end{array}$} & $\begin{array}{l}\text { Types of knowledge (terminology, } \\
\text { conceptual, or factual) }\end{array}$ & SMK \\
\hline & $\begin{array}{l}\text { Accurate and inaccurate knowledge (in } \\
\text { goals for use of representation) }\end{array}$ & SMK \\
\hline & Scientific appropriateness & SMK \\
\hline & Pedagogical appropriateness & PCK \\
\hline \multirow[t]{3}{*}{$\begin{array}{l}\text { Assessment plan and } \\
\text { rubric }\end{array}$} & $\begin{array}{l}\text { Types of knowledge (terminology, } \\
\text { conceptual, or factual) }\end{array}$ & SMK \\
\hline & Scientific appropriateness & SMK \\
\hline & Pedagogical appropriateness & PCK \\
\hline
\end{tabular}

Note. SMK indicates subject matter knowledge. PCK indicates pedagogical content knowledge. 
Table 3

Coding Types of Ideas Cited

\begin{tabular}{|c|c|c|}
\hline Type of idea & Definition & Example \\
\hline Principle & $\begin{array}{l}\text { A general or abstracted rule that is a } \\
\text { testable claim and can be applied to } \\
\text { multiple situations demonstrating } \\
\text { the same scientific phenomenon. } \\
\text { Principles can be explanatory or } \\
\text { descriptive and thus vary in their } \\
\text { usefulness for explaining scientific } \\
\text { phenomena. }\end{array}$ & $\begin{array}{l}\text { "The size of an object affects } \\
\text { the kind of sound it } \\
\text { makes." }\end{array}$ \\
\hline Definition & $\begin{array}{l}\text { Knowledge that is culturally agreed } \\
\text { upon (i.e., defined by standard } \\
\text { usage and/or cultural norms) rather } \\
\text { than constructed on the basis of } \\
\text { evidence (see Howe \& Jones, 1998, } \\
\text { for a description of arbitrary } \\
\text { knowledge). }\end{array}$ & $\begin{array}{l}\text { "Anything that buds and } \\
\text { begins its lifecycle as a } \\
\text { seed are plants." }\end{array}$ \\
\hline $\begin{array}{l}\text { Real-world } \\
\text { experience }\end{array}$ & $\begin{array}{l}\text { A particular experience from real life } \\
\text { based on one's everyday } \\
\text { interactions in the world. }\end{array}$ & $\begin{array}{l}\text { Linking the size of a car's } \\
\text { speakers to the amount of } \\
\text { bass one hears when the } \\
\text { car drives past. }\end{array}$ \\
\hline $\begin{array}{l}\text { Classroom } \\
\text { experience }\end{array}$ & $\begin{array}{l}\text { A particular experience that we knew } \\
\text { to stem from the prospective } \\
\text { teachers' experiences in their } \\
\text { placement classrooms. (One could } \\
\text { imagine other types of classroom } \\
\text { experiences, but in these data we } \\
\text { only identified classroom } \\
\text { experiences based in the field } \\
\text { placements.) }\end{array}$ & $\begin{array}{l}\text { As seen in cooperating } \\
\text { teacher's classroom: } \\
\text { "Tuning forks produce } \\
\text { vibrations that can be } \\
\text { observed by dipping the } \\
\text { object into a glass of water. } \\
\text { The water reacts to the } \\
\text { vibrations by splashing } \\
\text { onto the floor." }\end{array}$ \\
\hline
\end{tabular}

\& Hsi, 2000). For an example of a more in-depth analysis of teachers' knowledge integration than that which is presented here, see Davis (2004).

To measure accuracy, we coded each unique (nonredundant) scientific principle and definition as scientifically accurate or inaccurate. (For example, we considered "Large objects produce sounds that have different qualities" and "The size of an object affects the kind of sound it makes" to be equivalent, and we counted those as a single unique principle.) Inaccurate principles or definitions were not scientifically correct, incomplete to the point of being misleading, or both.

To measure principles' level of explanation, we used the American Association for the Advancement of Science (1993) Benchmarks as a guide. Developed by a diverse group of experts including educators, scientists, mathematicians, historians, and others, the benchmarks serve as one representation of what science content is appropriate to expect children of different ages to understand; they also, for 
our purposes, served to illustrate increasingly complex understanding of the same science topics. The K-2 benchmarks tend to describe scientific phenomena and identify simple generalizations. The benchmarks associated with higher grades tend to explain phenomena more, identifying more sophisticated generalizations, as well as mechanisms. We looked for benchmarks that were conceptually (or, in some cases, semantically) matched to the prospective teachers' principles to determine how sophisticated their demonstrated knowledge was (see Table 4).

Recall that we focused on one aspect of PCK - knowledge of instructional representations. Instructional representations need to be relevant to the science topic and pedagogically and scientifically appropriate. These dimensions actually capture aspects of the prospective teachers' subject matter knowledge and pedagogical content knowledge. We addressed these dimensions for three types of instructional representations the prospective teachers might have included in their unit plans.

For the prospective teachers' implicit instructional representations, which involved real-world experiences and classroom-based experiences within the written explanations of the subject matter knowledge in their unit plans, we coded whether the representations were relevant or irrelevant to the science topic and appropriate

Table 4

Coding Explanatory Level of Principles Based on Benchmarks

\begin{tabular}{|c|c|c|c|}
\hline $\begin{array}{l}\text { Example from } \\
\text { prospective } \\
\text { teacher data }\end{array}$ & $\begin{array}{l}\text { Corresponding benchmark } \\
\text { (AAAS, 1993) }\end{array}$ & $\begin{array}{l}\text { Grade } \\
\text { level code }\end{array}$ & $\begin{array}{l}\text { Type } \\
\text { of match }\end{array}$ \\
\hline $\begin{array}{l}\text { "Seeds require the } \\
\text { correct soil and } \\
\text { proper amount of } \\
\text { water and sunlight } \\
\text { to grow." }\end{array}$ & $\begin{array}{l}\text { "Plants and animals both } \\
\text { need to take in water, and } \\
\text { animals need to take in } \\
\text { food. In addition, plants } \\
\text { need light" (AAAS, 1993, } \\
\text { p. 119). }\end{array}$ & $\mathrm{K}-2$ & Conceptual match \\
\hline $\begin{array}{l}\text { "Petals are used to } \\
\text { attract animals." }\end{array}$ & $\begin{array}{l}\text { "Organisms interact with one } \\
\text { another in various ways } \\
\text { besides providing food. } \\
\text { Many plants depend on } \\
\text { animals for carrying their } \\
\text { pollen or dispersing their } \\
\text { seeds" (AAAS, 1993, p. } \\
\text { 116). }\end{array}$ & $3-5$ & $\begin{array}{l}\text { Match of } \\
\text { explanatory } \\
\text { power level } \\
\text { (not conceptual } \\
\text { match) }\end{array}$ \\
\hline $\begin{array}{l}\text { "When a very } \\
\text { high-pitched sound } \\
\text { is created, the sound } \\
\text { waves still travel } \\
\text { from the whistle } \\
\text { through the air, but } \\
\text { we can't hear it." }\end{array}$ & $\begin{array}{l}\text { "Vibrations in materials set } \\
\text { up wavelike disturbances } \\
\text { that spread away from the } \\
\text { source" (AAAS, 1993, p. } \\
\text { 90). }\end{array}$ & $6-8$ & Conceptual match \\
\hline
\end{tabular}


or inappropriate for teaching the topic. Appropriateness is broken into scientific and pedagogical appropriateness. For example, listening to music as a context for discussing the way one can distinguish between pitch and volume would be a relevant, scientifically appropriate, and pedagogically appropriate (real-world) experience. In teaching about the relationship between size and pitch, discussing the bass sounds produced by large car stereo speakers would not be scientifically appropriate because modern stereos affect pitch electronically, not physically.

For the prospective teachers' explicit instructional representations-developed explicitly to represent science ideas to children-we applied these same dimensions. We also described the type of knowledge their explicit instructional representations aimed at developing (i.e., terms, facts, or concepts), using the goals the prospective teachers articulated for their representations. Additionally, we coded whether the knowledge embedded in those articulated goals was scientifically accurate or inaccurate.

Finally, sometimes assessment plans embedded instructional representations, as well. As such, we coded the assessment plans and rubrics for the type of knowledge being assessed and how appropriate or inappropriate was the assessment approach, given the goals of the assessment plan and of the unit as a whole.

Where appropriate, we compared quantified characteristics of the two pairs' knowledge using Fisher's Exact statistical tests for two-by-two matrices involving small cell counts. This allowed comparison of, for example, the number of accurate versus inaccurate principles articulated by one pair versus the other pair.

After jointly developing the coding scheme, the two authors achieved over 90\% interrater reliability in assigning codes when working independently. Through iterative cycles of assertion generation, warrant identification, and discrepancy identification (Erickson, 1986), we developed a case study for each pair of prospective teachers. Detailed initial case narratives (Lincoln \& Guba, 1985; Stake, 2000) described and made assertions about the prospective teachers' science subject matter knowledge, their instructional representations, and other relevant aspects of their instruction. Each case narrative was then reviewed and edited by the other researcher, based on the full transcripts of all the interviews and written coursework, to identify confirming and disconfirming evidence. This verification process, plus regular meetings of the two researchers in which emerging findings were reviewed, contributed to the credibility (i.e., internal validity) of the assertions in the cases (Lincoln \& Guba, 1985; Merriam, 1988).

\section{Results}

We identified the most prevalent science topics in the interviews and unit plans, and two science topics emerged as particularly important to investigate further for each pair. We provide a general overview of each pair's subject matter knowledge. Then, for each science topic, we explore the pair's subject matter knowledge and their instruction, focusing most of our attention on how their subject matter knowledge appeared related to the instructional representations they developed. 


\section{Overview of the Pairs' Subject Matter Knowledge}

Our work is grounded in the assumption that teachers should hold better and stronger subject matter knowledge than they expect their students to develop. Stef and Lynn felt confident about their ability to teach the science involved in their unit. Jackie and Terry, on the other hand, stated in Interview 1 that they would need to do further research to be prepared. As described above, quality of science subject matter knowledge can be judged in terms of how integrated, scientifically accurate, and explanatory the ideas are. Stef and Lynn demonstrated better subject matter knowledge than did Jackie and Terry along each of those dimensions.

Integrated knowledge involves citing and linking multiple ideas of different types, such as principles, definitions, real-world experiences, and classroom experiences, although, in this context (mainly a written discussion of subject matter knowledge), one would expect to see more reliance on principles than on other types of ideas. Indeed, both pairs cited mainly principles in their written work (see Table 5). For example, Stef and Lynn wrote "When struck, objects begin to vibrate." Both pairs cited several definitions, as well. Stef and Lynn also made a few links to realworld or classroom experiences. For example, Stef and Lynn referred to a relevant and scientifically appropriate demonstration they saw their cooperating teacher do using a tuning fork in water to demonstrate waves. In contrast, Jackie and Terry did not cite any real-world experiences or classroom experiences in their written discussion.

Stef and Lynn also cited significantly more scientifically accurate principles than did Jackie and Terry (Fisher's Exact $p=.025$; see Table 5 for numbers of accurate, inaccurate, and unique principles). Over $80 \%$ of the scientific definitions and principles that Stef and Lynn drew on are scientifically accurate and can be integrated into a coherent understanding of sound. On the other hand, Jackie and Terry's knowledge included many factually incorrect propositions (e.g., referring to carbon monoxide instead of carbon dioxide) and conceptually confused ones (e.g., mixing up pollen, eggs, and seeds; anthropomorphizing plants).

Table 5

Characterizing Types of Ideas Cited in Pairs' Written Work

\begin{tabular}{lcc}
\hline & Stef \& Lynn & Jackie \& Terry \\
\hline Principles & 19 & 22 \\
Definitions & 7 & 9 \\
Real-world experiences & 3 & 0 \\
Classroom experiences & 1 & 0 \\
Total number of ideas & 30 & 31 \\
Total number of unique (nonredundant) principles & 18 (out of 19) & 20 (out of 22) \\
Number of accurate unique principles & 14 (out of 18) & 8 (out of 20) \\
Number of inaccurate unique principles & 4 (out of 18) & 12 (out of 20) \\
\hline
\end{tabular}


Table 6

Level of Explanations of Unique (Nonredundant) and Accurate Principles Cited

\begin{tabular}{lll}
\hline & Stef \& Lynn & Jackie \& Terry \\
\hline Grade 6-8 & 6 & 0 \\
Grade 3-5 & 8 & 4 \\
Grade K-2 & 0 & 4 \\
\hline
\end{tabular}

Furthermore, Stef and Lynn cited significantly more explanatory principles than did Jackie and Terry (Fisher's Exact $p=.010$; see Table 6). All of Stef and Lynn's principles were at least somewhat explanatory as opposed to descriptive. Their principles matched benchmarks for grades 3-5 and 6-8, going beyond what they expected their 2nd-grade students to learn. A typical example, "[When a very high-pitched sound is created], the sound waves still travel from the whistle through the air, but we can't hear it," mapped onto a similar level of explanation as a grade 6-8 benchmark. In contrast, when discussing the science knowledge a teacher must have, Jackie and Terry cited no principles that match benchmarks above the grade 3-5 level. Jackie and Terry's most explanatory principles were similar to their principle, "Plants provide us with clean air to breathe." Neither pair cited principles matching benchmarks at the 9-12 level. (In our analysis of the benchmarks document, we identified one 9-12 benchmark as potentially relevant to the topics in each pair's unit, but in neither case did the concept seem critical for the teachers to understand or discuss.)

Two main ideas in Stef and Lynn's unit plan were distinguishing pitch from volume and relating size and pitch. The relative quality of their subject matter knowledge in those areas was related to how well they could use it for teaching. For Jackie and Terry, two main ideas included their definition of plant and their understanding of plants' relations to humans. Their knowledge in both areas proved problematic, scientifically and pedagogically. We drew on varied data sources to characterize these differences in these pairs' instructional representations.

\section{How Stef and Lynn Taught About Pitch and Volume}

Stef and Lynn used the real-world application of playing opera music on a radio as an instructional representation to help students hear the distinction between pitch and volume. Their choice was scientifically and pedagogically appropriate since opera music (as opposed to, say, a children's song) can show fairly extreme and consistent pitch, allowing changes in volume to be more easily distinguished. They could easily provide the experience for children who were not familiar with opera. Stef and Lynn also appropriately linked this instructional representation to an experiment involving shaking metal washers to produce sounds with different pitches and volumes.

Furthermore, Stef and Lynn's assessment plan described how students would demonstrate an understanding of the causes of pitch and volume through performing 
a song for the class. The conceptual knowledge assessed was appropriate and important to the content in the unit, and the representation by which they assessed their students' knowledge of those concepts (i.e., the song) was scientifically and pedagogically appropriate, coming as it did after an instructional representation that clearly illustrated the differences between pitch and volume.

Stef and Lynn were able to use their knowledge about pitch and volume appropriately in developing instruction. Their use of opera music as an instructional representation demonstrated a productive set of links among their strong subject matter knowledge of pitch and volume, a real-world application of that knowledge, and a way to represent those ideas in the classroom. In their assessment plan, they asked their students to make a similar set of links.

\section{How Stef and Lynn Taught About Size and Pitch}

In contrast, Stef and Lynn's understanding of the relationship between size and pitch was problematic, as was their instructional plan. Stef and Lynn held an inaccurate idea discussed by diSessa (1993): They assumed that speed of vibration is related only to the size of the object, whereas other factors, such as rigidity or tension, actually also play a role.

In their discussion of the knowledge a teacher needs to teach their unit, Stef and Lynn cited a real-world experience that was not completely scientifically appropriate. They linked the size of a car's speakers to the amount of bass one hears when the car drives past. In reality, the amount of bass a modern stereo-and-speaker set can produce is driven electronically and is not necessarily dependent on the physical size of the speaker. Their representation, therefore, was misleading. Though larger objects often make lower pitched sounds than do smaller objects (e.g., consider cellos and violins), other factors, like tension, also matter. Finding an appropriate balance between accuracy and accessibility in teaching young children is quite challenging, but when inaccurate real-world applications, like this one, are used in classrooms, they may unintentionally promote misunderstandings for the students-or even for the teachers themselves. We show further examples of this concern in our discussion of Jackie and Terry.

\section{How Jackie and Terry Taught About What Defines Plants}

Jackie and Terry displayed an inaccurate understanding of what defines a plant. This general confusion pervaded Jackie and Terry's work and interviews. For example, in stating what they want children to understand as a result of their instructional representation, Jackie and Terry wrote: "Trees, flowers, and plants all fall under the category of being plants. This is because they all bud and rely on other forms of life to help them reproduce because they are nonlocomotive." This statement was problematic in several ways. Stating that "trees, flowers, and plants [are all] plants" was, at best, partially tautological, and, at worst, demonstrated their own confusion about plants. They may have meant to distinguish among trees (e.g., oaks, pines), plants that are grown mainly for their flowers (e.g., geraniums, daisies), typical 
potted houseplants (e.g., philodendrons), and others. Furthermore, Jackie and Terry did not explain their meaning for the word "bud." Last, their statement that all plants "rely on other forms of life to help them reproduce" was inaccurate since plants can also self-fertilize and fertilize other plants via air currents.

Thus, Jackie and Terry held a set of disconnected and largely incorrect propositions about plants. Furthermore, rather than focusing on their stated goal of helping students understand that all plants bud and rely on other forms of life to reproduce, the instructional representation Jackie and Terry developed, in fact, demonstrated the idea that all plants have roots (an idea that technically is itself inaccurate, though, perhaps, reasonable in an elementary context). They described a scenario in which the students were asked to recall a time when their parents planted or uprooted a young tree-an experience only a handful of 2nd graders are likely to have had, and not one easily brought into a classroom, though some students have probably seen uprooted houseplants. Thus, the knowledge embedded in the instructional representation was scientifically inappropriate, mismatched to the particular pedagogical goals for which it was developed, and pedagogically inappropriate. Jackie and Terry took as interchangeable two very different aspects of their propositional knowledge: (a) whether or not all plants bud and rely on other forms of life to reproduce and (b) whether or not all plants have roots. In other words, their instructional representation lacked alignment with their stated instructional goal. Recognizing that there are different facets to their ideas about plants—and distinguishing among them — might have helped these prospective teachers develop more appropriate real-world applications that, in turn, could promote more appropriate instructional representations.

\section{How Jackie and Terry Taught About Plants' Relation to Humans}

Jackie and Terry also presented humans as analogous to plants in inappropriate and misleading ways, especially with regard to each organism's parts, and were confused, in a general sense, about the distinction between flowers and plants and about the parts of each. For example, during a discussion of plant reproduction, the interviewer probed for clarification by asking Jackie and Terry to expand their thinking beyond the reproduction of flowering plants, like carnations and lilies, to the reproduction of a fern. Terry countered with the reproduction of grasses, and the interviewer asked if grasses have the parts of a flower. Jackie and Terry jointly stated that grasses do have the parts of a flower, but they are "somewhere underground." When asked specifically about plant parts (as distinct from parts of flowers), Jackie responded, "There's the stamen, the ovaries, the pistil" - all parts of a flower. Terry brought up some other plant parts, but then returned to a part specific to a flower. In this case, Jackie, in particular, seemed to confound flowers with plants.

This confusion may have been related to their understanding of the functions of the parts, as well. In discussing plant parts in the interviews, Jackie and Terry made an analogy between plants' roots and humans' legs several times. Jackie said, "If [plants] didn't have roots, they're not going to live long .... It's sort of like if we cut out one of our legs ... and it didn't get fixed, then we would die." Terry said the roots take in water, but Jackie was quick to note that plants also would not stand up without 
roots-“sort of like we wouldn't stand up if we didn't have our legs.” Although this statement is true in that roots of plants do provide structural support, it missed a main role of roots - to absorb water and some nutrients from the soil. Both prospective teachers used the roots-legs analogy multiple times and in multiple ways, and Jackie, in particular, never acknowledged the role of roots in absorbing water. From a scientific standpoint, assigning human characteristics based on structure and not function (and anthropomorphizing, in general) is problematic, though it can be acceptable in some instances (Treagust \& Harrison, 2000). Anthropomorphizing in an instructional representation may promote alternative conceptions in the children being taught. As was the case for Stef and Lynn when they held an incomplete understanding of the relationship between pitch and size, Jackie and Terry's scientific confusion here was, from a pedagogical standpoint, potentially problematic. They linked their weak subject matter knowledge of plants and humans to inappropriate applications of the ideas in the real world.

\section{Summary and Discussion}

Stef and Lynn articulated only 4 inaccurate principles out of the 18 principles they cited, and all of their principles fell at the 3-5 or 6-8 grade levels and, thus, were at least somewhat explanatory. Their understanding of pitch and volume allowed them to pick an effective instructional representation and develop an effective assessment plan. Though not investigated in this study, based on the literature we would expect their strong subject matter knowledge to enable them further to be better able to teach the content effectively (Carlsen, 1992; Rowan, Chiang, \& Miller, 1997) and to identify alternative conceptions held by their own students (Hashweh, 1987; Putnam, Heaton, Prawat, \& Remillard, 1992; Smith \& Neale, 1989). Stef and Lynn's knowledge, however, was not perfect. They overgeneralized the relationship between the size of an object and the pitch of the sound it makes (see diSessa, 1993). Their misleading car stereo representation-a real-world application-is likely to develop into inappropriate pedagogical content knowledge. In the other examples used by Stef and Lynn, the simplified relationship of size and pitch is adequate, though not complete.

Jackie and Terry's overgeneralizations were more extensive than Stef and Lynn's and scientifically problematic in almost all instances. Over half of the principles they articulated were inaccurate, and none of them fell above the grade 3-5 level of explanatory power. In their real-world applications, they linked plant parts to superficially similar parts of humans. Novice physics learners behave similarly, grouping physics problems based on superficial features rather than on more scientifically meaningful features (Chi, Glaser, \& Rees, 1982). Furthermore, Jackie and Terry seemed unable to prioritize the relative importance of the functions of the parts of plants. We hypothesize that one of their instructional representations-the flawed analogy to humans - is a precursor to their pedagogical content knowledge. This representation would likely promote the development of inaccurate scientific ideas among students (Hashweh, 1987; McDiarmid et al., 1989). 
Jackie and Terry's instructional representation about the roots of plants, a realworld application involving an uprooted tree, was also scientifically and pedagogically inappropriate and mismatched to their stated goals (helping students understand that all plants bud and rely on other forms of life to reproduce). Jackie and Terry appeared to see very different scientific ideas about plants as being interchangeable. Distinguishing better among ideas about plants might have allowed them to develop an instructional representation that was, at least, scientifically appropriatea first step toward developing representations that are also pedagogically appropriate.

In sum, Stef and Lynn developed effective representations based on real-world applications when their subject matter knowledge was strong and potentially misleading representations when their subject matter knowledge was weak. Jackie and Terry, too, developed poor representations based on real-world applications when their subject matter knowledge was weak. For both pairs, weak subject matter knowledge allowed—or, perhaps, forced - them to develop inappropriate representations, in keeping with other findings in the literature (e.g., Hashweh, 1987). We reiterate, though, that, given the realities of teacher preparation and elementary teaching, it is understandable and perhaps even to be expected that new elementary teachers would hold limited subject matter knowledge in science; we see it as teacher educators' responsibility to help them develop the knowledge and abilities they need to be effective, despite these limitations.

\section{A Perspective on the Development of Knowledge of Instructional Representations}

This work suggests a perspective on the development of one aspect of new elementary teachers' pedagogical content knowledge: their knowledge of instructional representations. This addresses an important hole in the literature (see Magnusson et al., 1999; van Driel et al., 1998, 2002), especially given that much of the empirical research on specific aspects of science teachers' PCK has focused on secondary teachers (see Appleton, 2003, for an important exception).

Most researchers discuss PCK as involving a transformation or translation of subject matter knowledge (e.g., Wilson, Shulman, \& Richert, 1987) that may also include developing subject matter knowledge through teaching, but emphasizes subject matter knowledge as the starting point. Others present the development of PCK as a process of integration of prerequisite subject matter knowledge and classroom experience (van Driel et al., 1998, 2002) — but, again, subject matter knowledge plays a key role, and real-life experiences do not. Though the literature has not explored this issue in great depth, this may well describe how some teachers-for example, those with strong subject matter knowledge - develop instructional representations for science.

In contrast, prospective elementary teachers typically start their careers with relatively sparse sets of propositional knowledge about any given science topic (Anderson \& Mitchener, 1994), but with a rich set of experiences in the physical world. Their reliance on real-world applications is understandably extensive, 
in particular given the large number of subject areas they are expected to teach. For teachers with limited subject matter knowledge, we hypothesize that real-world applications sometimes are key because they can serve as a mediating step between the limited subject matter knowledge, on the one hand, and the instructional representations, on the other. If the mediating step - the real-world application-is flawed, the instructional representation will be flawed, as well. For example, when Jackie and Terry inappropriately made links between their knowledge of humans and their knowledge of plants-connecting the less familiar ideas about plants to more familiar ideas about humans-the implicit instructional representations they developed were scientifically problematic. Likewise, when Stef and Lynn misunderstood a relationship between size and pitch, they drew on an inappropriate real-world application as an illustration.

Furthermore, inappropriate real-world applications or instructional representations can cause teachers to develop scientifically inaccurate propositional knowledge. Prospective teachers may rely too heavily on their real-world applications, even though those real-world applications are often not scientifically appropriate (see Yerrick et al., 2003). Teachers with limited subject matter knowledge, especially, need help in drawing on appropriate real-world applications. Providing this support (as we describe below) will not only help them develop more appropriate instructional representations for their classrooms, it will also help them develop their subject matter knowledge.

In other words, we believe that subject matter knowledge is certainly important; but, for prospective elementary teachers, we hypothesize that it cannot truly be a prerequisite for the development of pedagogical content knowledge as it may be for teachers with stronger subject matter knowledge. Instead, these new elementary teachers may develop their subject matter knowledge and PCK simultaneously. New elementary teachers draw on science activities to develop some aspects of their PCK (Appleton, 2003), and making accurate real-world applications may also help promote some of that development.

Note that our language here is tentative. We cannot develop a full-blown theoretical account of the development of the knowledge of instructional representations based on an exploratory analysis of four individuals - and we did not set out to do so. Rather, we intend to propose a new way of thinking about how that development might take place, to argue that the ways in which knowledge is developed may differ substantially for teachers with different characteristics or in different contexts and to call for further research on this issue. This perspective is intended to complement, rather than replace, existing perspectives on the development of PCK. Like Appleton (2003), we emphasize, however, that even new elementary teachers can develop PCK; they may simply follow a different path as they do so.

\section{Concluding Thoughts}

The ways in which prospective teachers link science ideas to the real world can serve as early indicators of the kinds of instructional representations they are likely to use with children. Furthermore, the instructional representations can highlight 
weaknesses in their subject matter knowledge (Hashweh, 1987; Magnusson et al., 1999). Once these weaknesses have been identified, teacher educators must help prospective teachers reflect on their knowledge and make links and distinctions where necessary. As a result, the prospective teachers' subject matter knowledge will become stronger at the same time as their instruction improves.

Yet prospective teachers have trouble using instructional representations embedded in curriculum materials and generate inappropriate real-world applications or analogies as they work to make sense of science concepts (Yerrick et al., 2003). As such, science teacher educators should help prospective elementary teachers learn to identify, critique, adapt, and use the instructional representations in curriculum materials as part of their science methods course (Davis, in press). Emphasizing instructional representations will help raise prospective teachers' awareness that all instructional representations are not equally effective. By providing them with explicit criteria for critiquing instructional representations they find in curriculum materials or develop themselves - criteria like scientific and pedagogical appropriatenessscience teacher educators can help the teachers be better prepared to use instructional representations effectively in their own teaching. Helping prospective teachers learn to critique, adapt, and use existing materials (including, for example, the models that can serve as instructional representations within science activities and lesson plans) also serves to ameliorate some of the challenges these teachers face as new teachers, allowing them to focus more of their attention, time, and energy on other critical tasks of elementary teaching.

Furthermore, science teacher educators should help prospective teachers learn to explain science principles by making connections to real-world applications. For example, many elementary science methods courses require prospective teachers to develop a unit plan for teaching a science concept or topic; a component of this unit plan is often a discussion of the science knowledge a teacher would need in order to teach the unit well. In our own science methods classes, we now ask the prospective teachers to provide this information in the form of answers to real-world questions that guide their instruction because this helps them make links and better integrate their knowledge. Moreover, it also provides us with a window into how they are thinking about these connections.

Future research should investigate the validity and generality of the perspective we have proposed on the development of knowledge of instructional representations. This perspective was developed through investigating a small number of prospective elementary science teachers, and it needs to be tested empirically with a larger number of prospective teachers. Furthermore, future research should continue to investigate the development of other aspects of PCK, such as knowledge of students' ideas. We have explored here a small but important piece of what teachers need to know to be effective science teachers.

\section{Acknowledgments}

This material is based upon research supported by a University of Michigan Horace Rackham Grant and Fellowship to the first author. The writing has been 
funded, in part, by a Presidential Early Career Award for Scientists and Engineers from the National Science Foundation, REC Grant \#0092610, also to the first author. However, any opinions, findings, and conclusions or recommendations expressed in this material are those of the authors. We appreciate the interest and cooperation of the prospective teachers who made the research reported here possible. We thank members of the TESG and CASES research groups at the University of Michigan, as well as Brian Foley, Garrett Scott, and three anonymous reviewers for their help in thinking about these ideas.

\section{References}

American Association for the Advancement of Science. (1993). Benchmarks for science literacy. New York: Oxford University Press.

Anderson, R. D., \& Mitchener, C. P. (1994). Research on science teacher education. In D. L. Gabel (Ed.), Handbook of research on science teaching and learning (pp. 3-44). New York: Macmillan.

Appleton, K. (2003). How do beginning primary school teachers cope with science? Toward an understanding of science teaching practice. Research in Science Education, 33, 1-25.

Ball, D. L., \& Bass, H. (2000). Interweaving content and pedagogy in teaching and learning to teach: Knowing and using mathematics. In J. Boaler (Ed.), Multiple perspectives on the teaching and learning of mathematics (pp. 83104). Westport, CT: Ablex.

Bransford, J. D., Brown, A. L., \& Cocking, R. R. (Eds.). (1999). How people learn: Brain, mind, experience, and school. Washington, DC: National Academy Press.

Carlsen, W. S. (1992). Closing down the conversation: Discouraging student talk on unfamiliar science content. Journal of Classroom Interaction, 27(2), 15-21.

Chi, M., Glaser, R., \& Rees, E. (1982). Expertise in problem solving. In R. Sternberg (Ed.), Advances in the psychology of human intelligence (Vol. 1, pp. 7-76). Mahwah, NJ: Erlbaum.

Clement, J. (1982). Students' preconceptions in introductory mechanics. American Journal of Physics, 50, 66-71.

Davis, E. A. (2003). Prompting middle school science students for productive reflection: Generic and directed prompts. The Journal of the Learning Sciences, $12,91-142$.

Davis, E. A. (2004). Knowledge integration in science teaching: Analyzing teachers' knowledge development. Research in Science Education, 34, 21-53.

Davis, E. A. (in press). Preservice elementary teachers' critique of instructional materials for science. Science Education.

diSessa, A. (1993). Toward an epistemology of physics. Cognition and Instruction, $10,105-225$.

Driver, R., Guesne, E., \& Tiberghien, A. (Eds.). (1985). Children's ideas in science. Philadelphia: Open University Press. 
Erickson, F. (1986). Qualitative methods in research on teaching. In M. C. Wittrock (Ed.), Handbook of research on teaching (pp. 119-161). New York: Macmillan.

Fernandez-Balboa, J., \& Stiehl, J. (1995). The generic nature of pedagogical content knowledge among college professors. Teaching and Teacher Education, 11, 293-306.

Gess-Newsome, J. (1999). Pedagogical content knowledge: An introduction and orientation. In J. Gess-Newsome, \& N. Lederman (Eds.), Examining pedagogical content knowledge: The construct and its implications for science education (pp. 3-17). The Netherlands: Kluwer Academic Publishers.

Grossman, P. (1990). The making of a teacher: Teacher knowledge and teacher education. New York: Teachers College Press.

Hartman, M. (2004). Situating teacher learning in the practice of mathematics and science teaching. Unpublished doctoral dissertation, University of Michigan, Ann Arbor.

Hashweh, M. (1987). Effects of subject-matter knowledge in the teaching of biology and physics. Teaching and Teacher Education, 3, 109-120.

Howe, A., \& Jones, L. (1998). Engaging children in science. Upper Saddle River, NJ: Merrill.

Interstate New Teacher Assessment and Support Consortium. (1992). Models standards for beginning teacher licensing and development: A resource for state dialogue. Washington, DC: Council of Chief State School Officers.

Lederman, N., Gess-Newsome, J., \& Latz, M. (1994). The nature and development of preservice science teachers' conceptions of subject matter and pedagogy. Journal of Research in Science Teaching, 31, 129-146.

Lincoln, Y., \& Guba, E. (1985). Naturalistic inquiry. London: Sage.

Linn, M. C., \& Eylon, B.-S. (1996, July). Lifelong science learning: A longitudinal case study. Paper presented at the Cognitive Science Conference, San Diego, CA.

Linn, M. C., Eylon, B.-S., \& Davis, E. A. (2004). The knowledge integration perspective on learning. In M. C. Linn, E. A. Davis, \& P. Bell (Eds.), Internet environments for science education (pp. 29-46). Mahwah, NJ: Erlbaum.

Linn, M. C., \& Hsi, S. (2000). Computers, teachers, and peers: Science learning partners. Hillsdale, NJ: Erlbaum.

Linn, M. C., \& Songer, N. B. (1991). Teaching thermodynamics to middle school students: What are appropriate cognitive demands? Journal of Research in Science Teaching, 28, 885-918.

Ma, L. (1999). Knowing and teaching elementary mathematics. Mahwah, NJ: Erlbaum.

Magnusson, S., Krajcik, J., \& Borko, H. (1999). Nature, sources, and development of pedagogical content knowledge for science teaching. In J. Gess-Newsome, \& N. Lederman (Eds.), Examining pedagogical content knowledge: The construct and its implications for science education (pp. 95-132). The Netherlands: Kluwer Academic Publishers.

McDiarmid, G. W., Ball, D. L., \& Anderson, C. W. (1989). Why staying one chapter ahead doesn't really work: Subject-specific pedagogy. In M. C. Reynolds 
(Ed.), Knowledge base for the beginning teacher (pp. 193-205). New York: Pergamon.

Merriam, S. B. (1988). Case study research in education: A qualitative approach. San Francisco: Jossey-Bass.

Minstrell, J. A. (1989). Teaching science for understanding. In L. B. Resnick, \& L. E. Klopfer (Eds.), Toward the thinking curriculum: Current cognitive research: 1989 ASCD Yearbook (pp. 129-149). Alexandria, VA: Association for Supervision and Curriculum Development.

National Council for Accreditation of Teacher Education. (1987). NCATE standards, procedures, and policies for the accreditation of professional education units: The accreditation of professional education units for the preparation of professional school personnel at basic and advanced levels. Washington, DC: Author.

National Research Council. (1996). National science education standards. Washington, DC: Author.

Putnam, R. T., Heaton, R. M., Prawat, R. S., \& Remillard, J. (1992). Teaching mathematics for understanding: Discussing case studies of four fifth-grade teachers. The Elementary School Journal, 93, 213-228.

Roth, W.-M., McGinn, M., \& Bowen, G. M. (1998). How prepared are preservice teachers to teach scientific inquiry? Levels of performance in scientific representation practices. Journal of Science Teacher Education, 9, 25-48.

Rowan, B., Chiang, F., \& Miller, R. (1997). Using research on employees' performance to study the effects of teachers on students' achievement. Sociology of Education, 70, 256-284.

Sherin, M. G. (2002). When teaching becomes learning. Cognition and Instruction, 20, 119-150.

Shulman, L. S. (1986). Those who understand: Knowledge growth in teaching. Educational Researcher, 15(2), 4-14.

Smith, D. C., \& Neale, D. C. (1989). The construction of subject matter knowledge in primary science teaching. Teaching and Teacher Education, 5, 1-20.

Stake, R. E. (2000). Case studies. In N. Denzin, \& Y. Lincoln (Eds.), Handbook of qualitative research (pp. 435-454). Thousand Oaks, CA: Sage.

Treagust, D., \& Harrison, A. (2000). In search of explanatory frameworks: An analysis of Richard Feynman's lecture "Atoms in Motion." International Journal of Science Education, 22, 1157-1170.

van Driel, J., De Jong, O., \& Verloop, N. (2002). The development of preservice chemistry teachers' pedagogical content knowledge. Science Education, 86, 572-590.

van Driel, J., Verloop, N., \& de Vos, W. (1998). Developing science teachers' pedagogical content knowledge. Journal of Research in Science Teaching, 35, 673-695.

White, B. (1993). Intermediate causal models: A missing link for science education? In R. Glaser (Ed.), Advances in instructional psychology (Vol. 4, pp. 177-252). Hillsdale, NJ: Erlbaum. 
Wilson, S. M., Shulman, L., \& Richert, A. (1987). 150 different ways of knowing: Representations of knowledge in teaching. In J. Calderhead (Ed.), Exploring teachers' thinking (pp. 104-124). London: Cassell Educational Limited.

Wolcott, H. F. (1994). Transforming qualitative data: Description, analysis, and interpretation. Thousand Oaks, CA: Sage.

Wu, H.-K. (2002). Middle school students' development of inscriptional practices in inquiry-based classrooms. Unpublished doctoral dissertation, University of Michigan, Ann Arbor.

Yerrick, R., Doster, E., Nugent, J., Parke, H., \& Crawley, F. (2003). Social interaction and the use of analogy: An analysis of preservice teachers' talk during physics inquiry lessons. Journal of Research in Science Teaching, 40, 443-463.

Zembal-Saul, C., Blumenfeld, P., \& Krajcik, J. (2000). Influence of guided cycles of planning, teaching, and reflection on prospective elementary teachers' science content representations. Journal of Research in Science Teaching, 37, 318-339.

Zembal-Saul, C., Krajcik, J., \& Blumenfeld, P. (2002). Elementary student teachers' science content representations. Journal of Research in Science Teaching, 39, 443-463. 